\title{
Client Related Changes Affecting Construction Schedule Performance
}

\author{
Abdulla Al Ameri', Nur Ain Ngah Nasaruddin²* \\ ${ }^{1}$ Faculty of Business and Technology Management, \\ Universiti Tun Hussein Onn Malaysia Address, 86400 Parit Raja, Batu Pahat, Johor, MALAYSIA \\ ${ }^{2}$ Faculty of Civil Engineering and Built Environment, \\ Universiti Tun Hussein Onn Malaysia Address, 86400 Parit Raja, Batu Pahat, Johor, MALAYSIA \\ *Corresponding Author
}

DOI: https://doi.org/10.30880/ijscet.2020.11.03.006

Received 12 February 2020; Accepted 18 June 2020; Available online 30 June 2020

\begin{abstract}
Majority of UAE construction works were reported experiencing changes during execution process which exerts adverse effects to project success. Among the negative impacts is the failing in achieving satisfactory schedule performance. This poor schedule performance is also common issue faced by construction works globally. This paper addressed a study on various client related factors causing changes and parameters that affecting project schedule performance. The study was conducted through quantitative method. The data was gathered through questionnaire survey amongst the practitioners from contractor and consultant organization engaged in construction project of UAE and analysed statistically using significant index value. Results obtained in this study highlighted lack of coordination, replacement of key personnel by clients and inadequate understanding of clients need as three major issues related to client which are responsible for changes in construction works. While delay in completion schedule, slower project progress and dispute between owner \& contractor are as major parameters affecting schedule performance. For correlation analysis, it was found that lack of coordination between the parties has significant correlation with delay in completion schedule, and dispute between owner \& contractor. Also replacement of key personnel from client has significant correlation with schedule delay that are additional works and re-work/redesign. These finding will be helpful for practitioner in prioritizing the factors of change and schedule measuring parameters for improving schedule performance.
\end{abstract}

Keywords: Changes, schedule performance, construction works

\section{Introduction}

In this construction industry, physical development can be achieved, and that is truly the wheel of the national economy (Habibi \& Kermanshachi, 2018). In the United Arab Emirates (UAE), it contributes 14 percent of the gross domestic product (Faridi \& El-Sayegh, 2006). It plays central role in the development, urbanization, and industrialization of the UAE (Ahmed, 2017). This has led to the need of successful completion of project. A successful project is carried out according to the pre-defined execution time, the budget allocated for the project, the quality requested by the client while respecting the safety condition of the workforce (Bajjou, Chafi, \& En-Nadi, 2017; Bajjou \& Chafi, 2018). Satisfactory performance of schedule is very essential for success of any project. Construction industry is regarded as schedule driven industry and hence achieving project completion within scheduled duration is basic 
requirement for success of project. However, it seems seldom for projects to be completed within scheduled time (Azis, Memon, Rahman, Nagapan, \& Latif, 2012). Schedule performance is affected adversely by several reasons. Among these, one of the common reasons is occurrence of changes. Changes may occur due to scope changes, design errors; adverse external factors. Reasons of the changes can arise due to working mechanism or policy of any of the stakeholders. This paper has addressed investigation of client related factors causing changes and also assessed correlation of the factors with various parameters of measuring success or failure of project schedule.

\section{Review of Related Works}

Project success has a significant impact on profitability and is considered as basic objective of the project management relating to that relate to the social and political environment of project management performance (Aggor, Souza, Abdalla, \& Hemazro, 2019). Success of the construction project is measuring by several parameters among which time and cost are very crucial parameters (Babu \& Raju, 2019). Time and cost of the project is very much dependant on the schedule of the project which must be followed as planned at earlier stage. Schedule delays in any construction activity adversely affect the project stakeholders (owner, contractor, and consultant). It can create adversarial relationships, distrust, litigation, arbitration, cash-flow problems, and a general feeling of apprehension towards each other (Seddeeq, Assaf, Abdallah, \& Hassanain, 2019). Project delivery within predetermined contract duration is the prime indicator of a successful project. In spite of the attention being given to managing construction schedules, majority of the construction projects fail to achieve time and cost-related objectives. This in turn causes negative impact on the performance of construction projects. It also affects project stakeholders such as the developer, contractor and the end-user of the facility (Narayanan, Kure, \& Palaniappan, 2019).

Schedule overrun in construction projects is a global phenomenon. Several researchers have pointed out poor schedule performance and time overrun in different worldwide. Huge numbers of construction projects are experiencing this important issue of overrun in time in Malaysia (Memon, Roslan, \& Zainun, 2014). In Pakistan also schedule performance is at satisfactory level (Memon, Memon, Soomro, \& Rahman, 2019). Effective schedule management is very necessary (Ismail et. al. 2013). Huge number of infrastructure projects in India face schedule delay (Deshmukh \& Menkudle, 2019). Poor schedule performance can measured by various parameters. In exercising the identification these schedule related parameters, literature review was conducted which results in listing 13 common parameters for measuring degree of success or failure of project schedule as presented in table 1 .

Table 1 - Parameters measuring success or failure of project schedule.

\begin{tabular}{cll}
\hline No & Parameters & Source \\
\hline 1 & Delay in completion schedule & Li, Love, \& Dawe (2000), Motaleb \& Kishk (2010) \\
2 & Logistics delays & Arain \& Pheng (2005) \\
3 & Slower project progress & Sambasivan \& Soon (2007) \\
4 & Decrease in productivity & Aibinu \& Jagboro (2002) \\
5 & Dispute between owner and contractor & Haseeb, Xinhai-Lu, Aneesa, Maloof, \& Wahab (2011) \\
6 & Decrease in productivity of workers & Kiswaki (2012) \\
7 & Additional specialist personnel & Motaleb \& Kishk (2010) \\
8 & Cost overruns due to inflation and fluctuations & Ramabodu \& Verster (2010) \\
9 & Addition of work & Arain \& Pheng (2005) \\
10 & Deletion of work & Arain \& Pheng (2005) \\
11 & Rework/redesign & Ramabodu \& Verster (2010) \\
12 & Work duration extension & Bower (2000) \\
13 & Productivity degradation & Bower (2000) \\
\hline
\end{tabular}

Failure or success in achieving project schedule performance is associated with several reasons. One of the reasons of schedule failure is occurrence of changes in construction works. Changes refer to the modification in the work plan or design. Change can occur at any stage of the projects which affect the work performance severely. A part of effect of change on project schedule, it has adverse impact of project budget as well as quality. Changes can be resulted from various events or activities such as revision. Revision of works is one of the most detrimental effects on project change which can increase the cost of the project to 10-15\% of the contract value (Love, 1999; Josephson, 2002). Li, Love, \& Dawe (2000) force that project managers should deal with situations where there is revision of works, extra costs or below standard quality work with projects that are changed. Aibinu \& Jagboro (2002) highlighted that Nigerian construction experiences several effects of change which include time exceeding, cost overrun, disputes, arbitration, total abandonment and litigation. Changes are noteworthy causes of disagreements or disputes which enhance the chance of contractual disputes (Sambasivan, Deepak, Salim, \& Ponniah, 2017). If the changes are prolonged, they can 
result in conflicts and lawsuits which serious challenges for project (Dadhich, Genovese, Kumar, \& Acquaye, 2015). Literature review and unstructured interviews were conducted to uncover common client related factors of changes occurring in construction projects as summarized in table 2.

Table 2 - Client related factors of changes.

\begin{tabular}{clcl}
\hline No & Factors of changes & No & Factors of changes \\
\hline 1 & Clients financial problems & 11 & Unprofessional clients \\
2 & Late payments & 12 & Clients authority change \\
3 & Delay in order issuance by clients & 13 & Inadequate site mobilization by contractor \\
4 & Owners' needs & 14 & Inadequate bidding documents by clients \\
5 & Economic inflation & 15 & Lack of coordination \\
6 & Elections and clients representative changes & 16 & Replacement of key personnel by clients \\
7 & Inadequate understanding of clients need & 17 & Lack of capable clients representative \\
8 & Conflicts with consultant and contractor & 18 & Skill shortage on certain trades \\
9 & Multiple contractors & 19 & Unsafe practices during construction \\
10 & Clients organizational problems & & \\
\hline
\end{tabular}

\section{Data Collection and Analysis}

Data collection for this study focused on collecting perception of contractors and consultants regarding parameters caused by clients in construction project which cause changes. Also the relation of the factors was evaluation for each parameter in failing to achieve satisfactory schedule performance. Gathering of this perception was done through structured Performa of question (Ishiyaku, Kasim \& Harir, 2017). Significance of the parameters investigated was measured based on the Significance index (S.I) value calculated using following formula as adopted by (Seddeeq, Assaf, Abdallah, \& Hassanain, 2019):

$$
S . I=\frac{\sum_{1}^{5} a_{i} n_{i}}{N}
$$

Where S.I represents Significance Index, $a_{1}$ to $a_{5}$ show the measurement scale and ni shown frequency for each measurement scale, $\mathrm{N}$ is the total number of responses.

\section{Characteristics of the Respondents}

Practitioners working at various levels and projects in construction industry were requested to participate in survey for assessing significance level of client related change parameters and failure of schedule performance. For this two hundred and eighteen practitioners were contacted electronically and in performance but only 100 positive responses could be collected in a period of 10 months. This made $45 \%$ of response rate which was considered acceptable for analysis as Almarri \& Abu-Hijleh (2017) had considered 23.9\% response acceptable for exploratory and AlGheth \& Sayuti (2019) also used 28\% response rate in drawing statistical analysis for research work. The participants of the survey were bearing different level of qualification and experiences. Demographic characteristics of the practitioners are presented in table 3 below.

Table 3 - Respondents profile for actual survey.

\begin{tabular}{|c|c|c|c|c|}
\hline No & Category & Items & Frequency & $\begin{array}{l}\text { Percentage of } \\
\text { responses }\end{array}$ \\
\hline \multirow[t]{2}{*}{1} & \multirow{2}{*}{ Organization } & Consultant & 30 & $52 \%$ \\
\hline & & Contractor & 28 & $48 \%$ \\
\hline \multirow[t]{3}{*}{2} & \multirow{3}{*}{$\begin{array}{l}\text { Highest academic } \\
\text { qualification }\end{array}$} & Bachelor degree & 38 & $66 \%$ \\
\hline & & Diploma & 6 & $10 \%$ \\
\hline & & Postgraduate & 14 & $24 \%$ \\
\hline \multirow[t]{4}{*}{3} & \multirow{4}{*}{$\begin{array}{l}\text { Working } \\
\text { experience in } \\
\text { construction } \\
\text { industry }\end{array}$} & 11-15years & 27 & $47 \%$ \\
\hline & & $6-10$ years & 8 & $14 \%$ \\
\hline & & Less than 5 years & 21 & $36 \%$ \\
\hline & & More than 15 Years & 2 & $3 \%$ \\
\hline 4 & Position in the & Executive management (or & 9 & $16 \%$ \\
\hline
\end{tabular}



construction
company supervisor)

Senior manager

Engineer
5

44
$9 \%$

$75 \%$

Table 3 illustrates that $52 \%$ of the respondents are from consultants' representative and $48 \%$ respondents are engaged in contractors' organizations. Further, it is seen that a significant number of participants with $66 \%$ of the respondents are only qualified engineering. Among remaining participants, $10 \%$ of the respondents are diploma holders and $24 \%$ of the respondents have attained post graduate studies. These respondents are working in construction sector since several years at various positions where majority of the respondents with $75 \%$ of the respondents are working on engineering position, $9 \%$ of the respondents are Executive managers and only $9 \%$ of the respondents are senior managers. These characteristics show that the respondents bear good level of knowledge regarding current scenario in the construction industry and can be considered suitable for providing real scenario of the problems faced in construction projects.

\section{Reliability Analysis}

Prior assessing the significance of the parameters, data was tested for reliability assessment. Reliability analysis ensures the degree of consistency of the data (Gliem \& Gliem, 2003). Its value is evaluated based Cronbach's alpha calculated through SPSS software package. For this study the Cronbach alpha was found as 0.812 for attributes of change while it was 0.86 for the attributes measuring schedule performance. These reliability values are higher than the required value of alpha i.e. 0.6 as suggested by Hair, Sarstedt, Hopkins, \& Kuppelwieser (2014). This confirms the consistency of the gathered data and data is considered suitable for further analysis.

\section{Significance of the Change and Schedule Measuring Parameters}

Each attribute of change caused by client in construction projects was evaluated for its significance level based on significance index value. Response of the practitioners was collected based on scale as 1 for Not Strong (NS), 2 for Less Strong (LS), 3 for Neutral (N), 4 for Strong (S) and 5 for Very Strong (VS). The response of the stakeholders participating in data collection and the overall ranking is shown in table 4.

Table 4 - Respondents profile for actual survey.

\begin{tabular}{clcccccc}
\hline \multirow{2}{*}{ No } & \multirow{2}{*}{ Parameters of changes } & \multicolumn{3}{c}{ Overall } & \multicolumn{2}{c}{ Consultant } & \multicolumn{2}{c}{ Contractor } \\
\cline { 3 - 7 } & & S.I & Rank & S.I & Rank & S.I & Rank \\
\hline 1 & Lack of coordination & 4.19 & 1 & 4.03 & 2 & 4.36 & 1 \\
2 & Replacement of key personnel by clients & 3.98 & 3 & 4.10 & 1 & 3.96 & 2 \\
3 & Inadequate understanding of clients need & 4.02 & 2 & 4.10 & 1 & 3.93 & 3 \\
4 & Multiple contractors & 3.74 & 5 & 3.87 & 6 & 3.89 & 4 \\
5 & Unprofessional clients & 3.78 & 4 & 3.73 & 8 & 3.82 & 5 \\
6 & Delay in order issuance by clients & 3.78 & 4 & 3.90 & 5 & 3.75 & 6 \\
7 & Lack of capable clients representative & 3.47 & 8 & 3.33 & 12 & 3.71 & 7 \\
8 & Conflicts with consultant and contractor & 3.69 & 6 & 4.00 & 3 & 3.64 & 8 \\
9 & Inadequate bidding documents by clients & 3.50 & 7 & 3.40 & 11 & 3.61 & 9 \\
10 & Clients authority change & 3.44 & 9 & 3.73 & 8 & 3.57 & 10 \\
11 & Economic inflation & 3.30 & 14 & 3.27 & 14 & 3.57 & 10 \\
12 & Clients financial problems & 3.42 & 10 & 3.73 & 8 & 3.43 & 11 \\
13 & Elections and clients representative changes & 3.24 & 16 & 3.77 & 7 & 3.39 & 12 \\
14 & Clients organizational problems & 3.36 & 12 & 3.63 & 9 & 3.32 & 13 \\
15 & Inadequate site mobilization by contractor & 3.14 & 17 & 3.53 & 10 & 3.25 & 14 \\
16 & Owners' needs & 3.34 & 13 & 3.93 & 4 & 3.21 & 15 \\
17 & Skill shortage on certain trades & 3.39 & 11 & 3.63 & 9 & 3.21 & 15 \\
18 & Unsafe practices during construction & 3.26 & 15 & 3.23 & 15 & 3.21 & 15 \\
19 & Late payments & 3.08 & 18 & 3.30 & 13 & 3.00 & 16 \\
\hline
\end{tabular}

Table 4 above highlights that lack of coordination between the parties is the most critical issue in causing change in any construction projects. However, there is little disagreement between the representative of consultants and contractors on this. Contractors consider lack of coordination is the most significant parameter by placing it at first rank 
while consultants have placed this parameter at 3rd rank. Inadequate understanding of the clients need is reported as 2nd major parameter. Consultants consider that this parameter is the most significant by placing at first rank while contractors have placed this parameter at 3rd rank. Third major issue causing changes due to client as perceived from analysis of data is replacement of key personnel by client. Consultants consider this issue as most significant and have ranked at $1^{\text {st }}$ place while contractors consider $3^{\text {rd }}$ place for this parameter.

Table 5 - Ranking of the schedule measuring parameters.

\begin{tabular}{llcccccc}
\hline \multirow{2}{*}{ No } & \multirow{2}{*}{ Schedule measuring parameters } & \multicolumn{2}{c}{ Overall } & \multicolumn{2}{c}{ Consultant } & \multicolumn{2}{c}{ Contractor } \\
\cline { 3 - 7 } & S.I & Rank & S.I & Rank & S.I & Rank \\
\hline 1 & Delay in completion schedule & 3.69 & 1 & 4.13 & 3 & 4.46 & 1 \\
2 & Slower project progress & 3.66 & 2 & 4.17 & 1 & 4.07 & 3 \\
3 & Dispute between owner and contractor & 3.61 & 3 & 4.17 & 1 & 3.96 & 2 \\
4 & Work duration extension & 3.55 & 4 & 3.80 & 6 & 3.71 & 6 \\
5 & Logistics delays & 3.51 & 5 & 3.90 & 7 & 3.89 & 4 \\
6 & Deletion of work & 3.43 & 7 & 3.57 & 11 & 3.82 & 5 \\
7 & Productivity degradation & 3.39 & 6 & 3.70 & 4 & 3.64 & 8 \\
8 & Decrease in productivity & 3.37 & 8 & 3.00 & 16 & 3.71 & 7 \\
9 & Additional specialist personnel & 3.34 & 9 & 3.43 & 9 & 3.29 & 12 \\
10 & Decrease in productivity of workers & 3.32 & 10 & 3.40 & 10 & 3.57 & 10 \\
11 & Rework/redesign & 3.29 & 11 & 3.53 & 5 & 3.21 & 16 \\
12 & Addition of work & 3.28 & 12 & 3.40 & 8 & 3.39 & 13 \\
13 & Cost overruns due to inflation and fluctuations & 3.18 & 13 & 3.13 & 12 & 3.07 & 17 \\
\hline
\end{tabular}

From table 5, it is evident delay in completion schedule is the most important attribute measuring schedule performance. Contractors also consider this parameter as most significant while consultant reported this parameter at 3rd level. From data analysis report, it is evident that 2nd major schedule performing attribute is slower project progress which consultants consider it as most significant parameter and contractor reported it at 3rd rank. Dispute between owner and contractor is found as 3rd ranked parameter while consultant consider this as the most significant parameter of schedule delay and contractor has ranked this at 3rd level. Two tailed Spearman correlation test was performed to assess the correlation between change related factors and schedule measuring parameters. The results for Spearman test obtained from SPSS are summarized in table 6.

Table 6 - Correlation matrix between changes related factors and schedule measuring parameters.

\begin{tabular}{|c|c|c|c|c|c|c|c|c|c|c|c|c|c|}
\hline \multirow[b]{2}{*}{$\begin{array}{l}\text { Change } \\
\text { factors/ }\end{array}$} & \multicolumn{13}{|c|}{ Schedule parameters } \\
\hline & 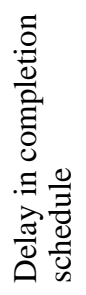 & 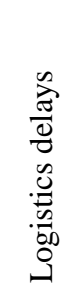 & 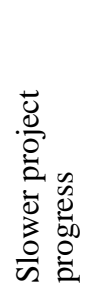 & 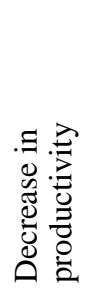 & 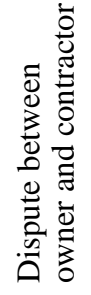 & 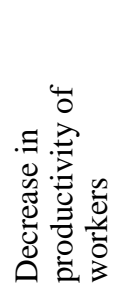 & 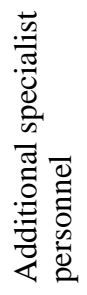 & 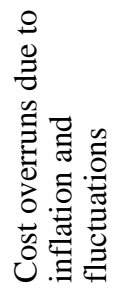 & 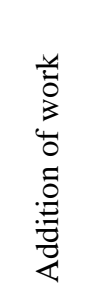 & 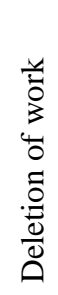 & 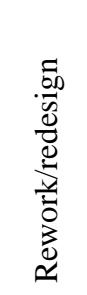 & 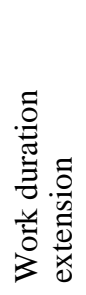 & 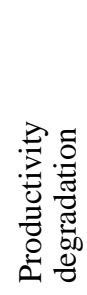 \\
\hline $\begin{array}{l}\text { Lack of } \\
\text { coordination }\end{array}$ & $.306^{* *}$ & .138 & $.226^{*}$ & .120 & $.272 * *$ & .137 & $.226^{*}$ & .056 & $.221^{*}$ & .168 & .182 & $.230^{*}$ & .006 \\
\hline $\begin{array}{l}\text { Replacement } \\
\text { of key } \\
\text { personnel by } \\
\text { clients }\end{array}$ & $.215^{*}$ & .092 & $.233 *$ & $.208 *$ & $.253^{*}$ & .122 & .195 & .146 & $.370 * *$ & .057 & $.296 * *$ & .006 & $.255^{*}$ \\
\hline $\begin{array}{l}\text { Inadequate } \\
\text { understanding } \\
\text { of clients need }\end{array}$ & .117 & $.313^{* *}$ & -.103 & .125 & $.240^{*}$ & .165 & .106 & .094 & .176 & .035 & $.291 * *$ & .091 & $.309^{* *}$ \\
\hline $\begin{array}{l}\text { Multiple } \\
\text { contractors }\end{array}$ & $.256^{*}$ & $.216^{*}$ & .123 & $.231^{*}$ & $.263 * *$ & .058 & $.279 * *$ & .037 & $.254^{*}$ & .009 & .164 & $.200^{*}$ & .071 \\
\hline $\begin{array}{l}\text { Unprofessional } \\
\text { clients }\end{array}$ & $.268 * *$ & .118 & $.278 * *$ & .133 & $.291 * *$ & .006 & .189 & .073 & .185 & .054 & $.292 * *$ & .039 & $.282 * *$ \\
\hline
\end{tabular}




\begin{tabular}{|c|c|c|c|c|c|c|c|c|c|c|c|c|c|}
\hline $\begin{array}{l}\text { Delay in order } \\
\text { issuance by } \\
\text { clients }\end{array}$ & $.204^{*}$ & .190 & .089 & .158 & $.247^{*}$ & -.028 & .084 & .189 & .120 & $.226^{*}$ & .130 & $.226^{*}$ & $.234^{*}$ \\
\hline $\begin{array}{l}\text { Lack of } \\
\text { capable clients } \\
\text { representative }\end{array}$ & $.248^{*}$ & .059 & .158 & .063 & .192 & .028 & .186 & .163 & .155 & .195 & $.239 *$ & $.226^{*}$ & $.234^{*}$ \\
\hline $\begin{array}{l}\text { Conflicts with } \\
\text { consultant and } \\
\text { contractor }\end{array}$ & $.233^{*}$ & -.001 & $.299 * *$ & .073 & $.209 *$ & .122 & -.004 & .074 & .184 & -0.22 & .173 & .103 & .192 \\
\hline $\begin{array}{l}\text { Inadequate } \\
\text { bidding } \\
\text { documents by } \\
\text { clients }\end{array}$ & $.367 * *$ & $.199 *$ & .196 & .125 & $.219^{*}$ & $.212 *$ & .044 & $.225^{*}$ & $.248^{*}$ & .071 & $.233^{*}$ & .175 & .189 \\
\hline $\begin{array}{l}\text { Clients } \\
\text { authority } \\
\text { change }\end{array}$ & $.286^{* * *}$ & $.259^{* *}$ & .141 & $.265^{* *}$ & .179 & $.222 *$ & .110 & $.247^{*}$ & .186 & .195 & $.253^{*}$ & .175 & $.240^{*}$ \\
\hline $\begin{array}{l}\text { Economic } \\
\text { inflation }\end{array}$ & .161 & .131 & -.223 & .118 & .121 & .111 & .188 & $.244^{*}$ & .182 & .014 & .113 & $.215^{*}$ & .108 \\
\hline $\begin{array}{l}\text { Clients } \\
\text { financial } \\
\text { problems }\end{array}$ & $.255^{*}$ & .045 & .191 & .176 & .191 & $.306^{* *}$ & .130 & $.227^{*}$ & $.251 *$ & .155 & $.214 *$ & .141 & $.345^{* *}$ \\
\hline $\begin{array}{l}\text { Elections and } \\
\text { clients } \\
\text { representative } \\
\text { changes }\end{array}$ & $.250^{*}$ & .159 & $.255^{*}$ & -.002 & $.252 *$ & $.282^{* *}$ & .131 & .157 & $.199 *$ & .064 & $.242 *$ & .121 & $.303^{* *}$ \\
\hline $\begin{array}{l}\text { Clients } \\
\text { organizational } \\
\text { problems }\end{array}$ & $.285^{* *}$ & .126 & .127 & .001 & $.244^{*}$ & -.011 & .103 & .110 & .153 & .063 & $.268 * *$ & $.208^{*}$ & .148 \\
\hline $\begin{array}{l}\text { Inadequate site } \\
\text { mobilization } \\
\text { by contractor }\end{array}$ & .164 & .101 & $.209^{*}$ & $.216^{*}$ & .189 & .151 & .129 & -.037 & -.043 & .060 & .050 & $.219^{*}$ & .125 \\
\hline Owners' needs & .195 & .134 & $.267 * *$ & -.030 & .111 & .070 & -.011 & .060 & $.231^{*}$ & .042 & .185 & -.011 & .162 \\
\hline $\begin{array}{l}\text { Skill shortage } \\
\text { on certain } \\
\text { trades }\end{array}$ & .176 & .105 & $.217^{*}$ & .147 & .177 & $.298 * *$ & -.058 & .086 & .193 & .137 & .170 & .045 & .185 \\
\hline $\begin{array}{l}\text { Unsafe } \\
\text { practices } \\
\text { during } \\
\text { construction }\end{array}$ & -.075 & $-.198 *$ & -.167 & -.067 & .081 & -.043 & .164 & .146 & -.022 & -.012 & -.112 & .150 & -.013 \\
\hline Late payments & .067 & .149 & .094 & .100 & $.243^{*}$ & .218 & .163 & .131 & $.249 *$ & -.021 & $.285^{* * *}$ & .122 & $.219^{*}$ \\
\hline
\end{tabular}

Based on table 6 it can be reported that the change related most significant factor that is lack of coordination between the parties has significant correlation with delay in completion schedule, and dispute between owner \& contractor at $99 \%$ confidence level. Theoretically also this is very true. If there is no or very less coordination between the parties working together for any common task, it can delay the project as well as create misunderstanding leading to disputes. In this study second major parameter of change is replacement of key personnel from client. This has significant correlation with two parameters of schedule delay which are additional works and re-work/redesign. Inadequate understanding of the client need is third major factor of change which is found significantly correlated with logistic delays, rework/redesign and productivity degradation.

\section{Conclusions}

Changes in construction projects are very common issue and faced frequently in construction project of UAE. Changes apparently affect the schedule performance which lead to the failure of the project. Changes can occur due to various reasons caused by different stakeholder. This paper has shown an investigation on change related issue occurred in construction project due to client and also parameters measuring schedule performance in construction. A correlation matrix was developed through two tailed Spearman correlation test. From statistical analysis of the survey data gathered for this paper it was found that lack of coordination, replacement of key personnel by clients and inadequate understanding of clients need are three major issues related to client which are responsible for changes in construction works. These affect severely on various schedule performance measuring parameters where major 
parameters affected are delay in completion schedule, slower project progress and dispute between owner \& contractor. These finding are very useful in pointing out various possible issue which can occur due to negligence of client to causes of changes. It is also helpful for practitioner in prioritizing the factors of change and schedule measuring parameters for improving schedule performance.

\section{Acknowledgement}

The authors would like to thank the University Tun Hussein Onn Malaysia for assisting and supporting this study.

\section{References}

Aggor, K., Souza, L.D, Abdalla. E, and Hemazro, F.S. 2019. Examining Project Execution on Time, Quality, and Budget within the Ghanaian Construction Industry, Project and Quality, 127: 52688-52700

Ahmed, A. 2017. Fragmentation Problems and Management Strategies in the UAE Construction Industry, Doctoral dissertation, Heriot-Watt University

Aibinu, A and Jagboro, G. 2002. The effects of construction delays on project delivery in the Nigerian construction industry. International Journal of Project Management, 20(8):593-599

AlGheth, A. and Sayuti, M. I. 2019. An Investigation of Causes of Delay Affecting the United Arab Emirates Construction Industry. In AWAM International Conference on Civil Engineering, pp. 403-413

Almarri, K., and Abu-Hijleh, B. 2017. Critical Success Factors for Public Private Partnerships in the UAE Construction Industry-A Comparative Analysis between the UAE and the UK. Journal of Engineering, Project \& Production Management, 7(1)

Arain, F.M. and Pheng L.S. 2005. The potential effects of variation orders on institutional building projects. Facilities, 23(11/12):496-510

Azis A.A.A, Memon A.H, Rahman I.A, Nagapan S, Latif Q.B.A.I. 2012. Challenges faced By Construction Industry in Accomplishing Sustainablity Goals, IEEE Symposium on Business, Engineering and Industrial Applications (ISBEIA) Babu V.R. and Raju A.S. 2019. A Study on Cost and Time Overrun in Costruction Projects, Universal Review, VIII(I): 615-619

Bajjou M.S and Chafi A. 2018. Empirical study of schedule delay in Moroccan construction projects, International Journal of Construction Management, DOI:10.1080/15623599.2018.1484859

Bajjou M.S, Chafi A, En-Nadi A. 2017. The potential effectiveness of lean construction tools in promoting safety on construction sites. Int J Eng Res Afr. 33:179-193

Bower, D. 2000. A systematic approach to the evaluation of indirect costs of contract variations. Construction Management \& Economics, 18(3):263-268.

Dadhich, P., Genovese, A., Kumar, N., and Acquaye, A. 2015. Developing sustainable supply chains in the UK construction industry: A case study. International Journal of Production Economics, 164:271-284

Deshmukh S.S. and Menkudle S.D. 2019. Case Study on "Budget and Schedule Overrun during the Construction phase of Project, International Research Journal of Engineering and Technology (IRJET), 06(04):353-356

Faridi A.S., El-Sayegh S. M. 2006. Significant factors causing delay in the UAE construction industry. Construction Management and Economics. 24(11):1167-1176

Gliem, J. A., and Gliem, R. R. 2003. Calculating, interpreting, and reporting Cronbach's alpha reliability coefficient for Likert-type scales. Midwest Research-to-Practice Conference in Adult, Continuing, and Community Education.

Habibi, M., and Kermanshachi, S. 2018. Phase-based analysis of key cost and schedule performance causes and preventive strategies: Research trends and implications", Engineering, Construction and Architectural Management, 25(8): 1009-1033, https://doi.org/10.1108/ECAM-10-2017-0219 
Hair Jr, J. F., Sarstedt, M., Hopkins, L., and Kuppelwieser, V. G. 2014. Partial least squares structural equation modeling (PLS-SEM). European Business Review, 26(2):106-121

Haseeb, M., Xinhai-Lu, Aneesa, B., Maloof, U.-D., \&Wahab, R. 2011. Problems of proejcts and effects of delays in the construction industry of Pakistan. Australian Journal of Business and Management Research, 1(5):41-50

Ishiyaku, B., Kasim, R., \& Harir, A.I. 2017. Confirmatory factoral validity of public housing satisfaction constructs, Cogent Business and Management, 4 (1), 1359458

Ismail, I., Rahman, I.A., Memon, A.H., Karim, A.T.A. 2013. Application of Time Management Tools and Techniques by Construction Industry Players: A Comparative Study between Kedah and Kelantan, Proceedings of 2nd International Conference On Global Optimization and Its Applications 2013 (ICoGOIA2013) Avillion Legacy Melaka Hotel, Malaysia 28-29 August 2013

Josephson P, L. B. 2002. Illustrative benchmarking rework and rework costs in Swedish construction Industry. Journal of Management and Engineering, 76-83

Kikwasi, G.J. 2012. Causes and effects of delays and disruptions in construction projects in Tanzania, Australasian Journal of Construction Economics and Building, Conference Series, 1 (2):52-59

Li, H., Love, P., and Dawe, D. 2000. Effects of overtime work and additional resources on project cost and quality. Engineering Construction and Architectural Management, 7(3):211-220

Love P.E.D, 1999. Determining the Casual structure of rework influences in construction. Construction Management Economy, 505-517

Memon A.H, Roslan N and Zainun N.Y. 2014. Improving Time Performance in Construction Projects: Perspective of Contractor, Journal of American Science, 10(8):46-50

Memon A.Q, Memon A.H, Soomro M.A. and Rahman I.A. 2019. Common Factors Affecting Time and Cost Performance of Construction Projects in Pakistan, Pakistan Journal of Science, 71 (4 Suppl.): 64-68

Motaleb, O., and Kishk, M. 2010. An investigation into causes and effects of construction delays in UAE. In Proceedings of 26th Annual ARCOM Conference:6-8)

Narayanan S, Kure A.M and Palaniappan S. 2019. Study on Time and Cost Overruns in Mega Infrastructure Projects in India, J. Inst. Eng. India Ser. A. 100(1):139-145

Ramabodu, M. and Verster, J. 2010. Factors contributing to cost overrun of construction proejcts. ASOCSA 5th built Environment Conferrence. Durban

Sambasivan, M., and Soon, Y.W. 2007. Causes and effects of delays in Malaysian construction industry. International Journal of project management, 25(5):517-526

Sambasivan, M., Deepak, T. J., Salim, A. N., and Ponniah, V. 2017. Analysis of delays in Tanzanian construction industry: Transaction cost economics (TCE) and structural equation modeling (SEM) approach. Engineering, Construction and Architectural Management, 24(2):308-325

Seddeeq A.B, Assaf S, Abdallah A and Hassanain M.A. 2020. Time and Cost Overrun in the Saudi Arabian Oil and Gas Construction Industry, Buildings, 9(41):1-17, doi:10.3390/buildings9020041 